\title{
Hemojuvelin regulates the innate immune response to peritoneal bacterial infection in mice
}

\author{
Qian Wu ${ }^{1,2,3}$, Yuanyuan Shen ${ }^{1,3}$, Yunlong Tao ${ }^{1}$, Jiayu Wei ${ }^{1}$, Hao Wang ${ }^{1,2}$, Peng An ${ }^{1}$, Zhuzhen Zhang ${ }^{1}$, \\ Hong Gao ${ }^{1}$, Tianhua Zhou ${ }^{1}$, Fudi Wang ${ }^{1,2, *}$, Junxia Min ${ }^{1, *}$ \\ ${ }^{1}$ The First Affiliated Hospital, Institute of Translational Medicine, School of Public Health, Collaborative Innovation Center for \\ Diagnosis and Treatment of Infectious Diseases, School of Medicine, Zhejiang University, Hangzhou, China; ${ }^{2}$ Department of \\ Nutrition, Precision Nutrition Innovation Center, School of Public Health, Zhengzhou University, Zhengzhou, China
}

Hereditary hemochromatosis and iron imbalance are associated with susceptibility to bacterial infection; however, the underlying mechanisms are poorly understood. Here, we performed in vivo bacterial infection screening using several mouse models of hemochromatosis, including $\mathrm{Hfe}\left(\mathrm{Hfe}^{-l-}\right)$, hemojuvelin $\left(\mathrm{Hj}^{-l-}\right)$, and macrophage-specific ferroportin-1 $\left(\mathrm{Fpn}^{f l f t}\right.$;

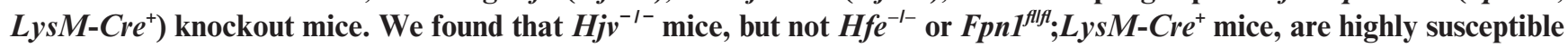
to peritoneal infection by both Gram-negative and Gram-positive bacteria. Interestingly, phagocytic cells in the peritoneum of $\mathrm{Hjv}^{-1-}$ mice have reduced bacterial clearance, IFN- $\gamma$ secretion, and nitric oxide production; in contrast, both cell migration and phagocytosis are normal. Expressing $\mathrm{Hjv}$ in RAW264.7 cells increased the level of phosphorylated Stat1 and nitric oxide production. Moreover, macrophage-specific $\mathrm{Hj} v$ knockout mice are susceptible to bacterial infection. Finally, we found that Hjv facilitates the secretion of IFN- $\gamma$ via the IL-12/Jak2/Stat4 signaling pathway. Together, these findings reveal a novel protective role of $\mathrm{Hjv}$ in the early stages of antimicrobial defense.

Keywords: hemochromatosis; hemojuvelin; iron; innate immune; macrophage

Cell Discovery (2017) 3, 17028; doi:10.1038/celldisc.2017.28; published online 15 August 2017

\section{Introduction}

In the 1960s, researchers first suggested a link between iron metabolism and the immune system [1]. Since then, many iron-related genes have been found to play a role in immune function. For example, the proteins lactoferrin, hepcidin, and Hfe have all been found to modulate the host defense against bacterial infection [2-6]. Moreover, the expression of several genes involved in iron metabolism, including hemojuvelin $(H J V)$ [7], hepcidin $(H A M P)$ [8], and ferroportin1 $(F P N 1)[9,10]$, are modulated during inflammation. Interestingly, a recent case report described a patient with hemochromatosis who died from bacterial

\footnotetext{
${ }^{3}$ These authors contributed equally to this work.

*Correspondence: Fudi Wang

Tel: +86 571 88206385; Fax: +86 57188206385

E-mail: fudiwang.lab@gmail.com or fwang@zju.edu.cn or Junxia Min

Tel: +86 57188206385 ; Fax: +86 57188206385

E-mail: junxiamin@zju.edu.cn

Received 10 May 2017; accepted 13 July 2017
}

infection [11]. These findings prompted us to investigate the putative role of hemochromatosis-related genes in bacterial infection. We therefore screened several hemochromatosis mouse models for their immune phenotype and susceptibility to bacterial infection.

HJV is a bone morphogenetic protein (BMP) co-receptor that regulates the expression of hepcidin [12]. In humans, mutations in the $H J V$ gene cause juvenile hemochromatosis [13]. In mice, deleting $H j v$ expression causes a similar iron-overload phenotype $[7,14]$. HJV is also a member of the repulsive guidance molecule (RGM) family [15]. However, the role of HJV in the immune response is currently unknown. Recent studies suggest that two other RGM family members - RGMa and RGMb - play a role in immune regulation. For example, RGMa is found in bone marrow-derived dendritic cells, where it modulates $\mathrm{T}$ cell responses [16]. RGMb is strongly expressed in macrophages, and increased IL-6 levels were measured in macrophages isolated from $R g m b$-knockout mice [17]. Notably, the Hjv gene 
(also known as $R G M c$ ) is also expressed in macrophages [17], and studies suggest that lipopolysaccharide (LPS) stimulation induces organ-specific patterns of Hjv expression [7]. However, whether Hjv plays a role in the immune system's response to bacterial infection is currently unknown. Here, we used an acute infection mouse model to investigate the potential immunomodulatory roles of hemochromatosis genes. Our results indicate that $\mathrm{Hjv}$ plays a major role in mediating the host innate immune response to bacterial infection.

\section{Results}

\section{Hjv-knockout mice have increased susceptibility to bacterial infection}

To investigate the function of hemochromatosisrelated genes in response to acute bacterial infection, we administered an intraperitoneal (i.p.) injection of a lethal dose of the Gram-negative bacterium Salmonella typhimurium (S. typhimurium) [5, 18] to the following hemochromatosis mouse models: Hfe-knockout $\left(H f e^{--}\right)$mice (Figure 1a), hemojuvelin-knockout $\left(\mathrm{Hjv}^{--}\right)$mice (Figure 1b), and macrophage-specific ferroportin1-knockout $\left(\mathrm{Fpn}^{\mathrm{fllf}} ; \mathrm{Lys} \mathrm{M}-\mathrm{Cr} \mathrm{C}^{+}\right)$mice (Figure 1c). Although all three models are reported to develop systemic iron overload [9], only the $\mathrm{Hjv}^{-/-}$mice were highly susceptible to $S$. typhimurium infection, reaching $100 \%$ mortality within $20 \mathrm{~h}$ of infection.

Two factors may contribute to the high sensitivity of $\mathrm{Hjv}^{-/-}$mice to bacterial infection. First, of these three models of hemochromatosis, $\mathrm{Hjv}^{-1-}$ mice develop the most severe form of iron overload; second, $\mathrm{Hjv}^{--}$mice have the lowest basal hepcidin levels. With respect to the first factor, iron overload has been shown to facilitate bacterial proliferation $[19,20]$. Consistent with this finding, the $\mathrm{Hjv}^{-/-}$mice had significantly more bacteria in the major organs and peritoneal fluid compared with wild-type mice (Figure 1d). In order to reduce the tissue iron burden in $\mathrm{Hjv}^{-/-}$mice to wild-type levels, we fed 4-week-old $\mathrm{Hjv}^{-1-}$ mice an iron-deficient (ID) diet for four weeks producing $\mathrm{Hjv}^{-1-}$-ID mice, which had comparable iron contents compared with wild-type mice (Supplementary Figures S1A and C). Injecting Escherichia coli into both $\mathrm{Hjv}^{-1-}$ and $\mathrm{Hjv}$ ${ }^{-1-}$-ID mice caused high mortality (Figure 1e). Given its relatively higher safety compared with $S$. typhimurium, we used $E$. coli infection for further experiments.

Consistent with increased mortality, the peritoneal cavity of $\mathrm{Hjv}^{-1-}$-ID mice contained higher levels of bacterial colony-forming units (CFUs) (Figure 1f). Thus, decreasing iron levels to wild-type levels was not sufficient to fully restore bacterial clearance in $\mathrm{Hjv}^{-/-}$ mice; therefore, factors other than iron overload likely contribute to the susceptibility of $\mathrm{Hjv}^{-/-}$mice to bacterial infection.

Hepcidin, the downstream target of Hjv encoded by the Hamp gene, has been reported to regulate inflammatory responses in mice [4]. Moreover, hepcidinknockout mice are sensitive to LPS stimulation [4]. Because hepcidin levels are low in $\mathrm{Hjv}^{-/-}$mice under basal conditions [7], we hypothesized that low hepcidin levels may contribute to the high susceptibility of $\mathrm{Hjv}^{-/-}$ mice to bacterial infection.

To test this hypothesis, we challenged $\mathrm{Hjv}^{-/-}$ mice with LPS and D-galactosamine [21] to induce endotoxic shock. We found that the mortality rate was similar between LPS-treated $\mathrm{Hjv}^{-/-}$mice and LPS-treated wild-type mice (Figure 1g). Interestingly, LPS stimulation induces hepcidin in $\mathrm{Hjv}^{--}$mice [7], and Hamp mRNA levels were similar between wild-type and $\mathrm{Hjv}^{-1-}$ mice following $\mathrm{E}$. coli infection (Supplementary Figure S2A). Moreover, serum TNF- $\alpha$ levels (measured $1 \mathrm{~h}$ after LPS stimulation) and IL-6 levels (measured $2.5 \mathrm{~h}$ after LPS stimulation) were similar between $\mathrm{Hjv}^{-1-}$ and wild-type mice (Supplementary Figure S2B and C). Taken together, these results suggest that reduced hepcidin expression does not contribute significantly to the increased mortality of $\mathrm{Hjv}^{-/-}$mice in response to bacterial infection.

To determine whether $\mathrm{Hjv}^{-/-}$mice are also susceptible to infection by Gram-positive bacterium, we gave $\mathrm{Hjv}^{-1-}$ and wild-type mice a lethal i.p. dose of the Gram-positive bacterium Staphylococcus aureus (S. aureus) and found considerably higher mortality in the infected $\mathrm{Hjv}^{-/-}$mice (Figure $1 \mathrm{~h}$ ). Thus, our acute lethal infection experiments indicate that $\mathrm{Hjv}^{-/-}$mice are highly susceptible to infection by both Gramnegative and Gram-positive bacteria, suggesting that Hjv may play an essential role in the host defense against bacterial infection.

\section{Impaired microbial clearance in $\mathrm{Hj}^{-1-}$ macrophages and neutrophils}

Our findings suggest that bacterial clearance is impaired in $\mathrm{Hjv}^{-1-}$ mice. However, bacteremia induced by an intravenous (i.v.) injection of $E$. coli $[22,23]$ caused similar mortality between $\mathrm{Hjv}^{-/-}$and wild-type mice (Figure 2a). Houghton et al. [18] reported that impaired macrophage function within the peritoneal cavity can result in bacterial dissemination to other sites. Thus, local defense processes are partially independent of systemic protection and may play an essential role in host survival. 

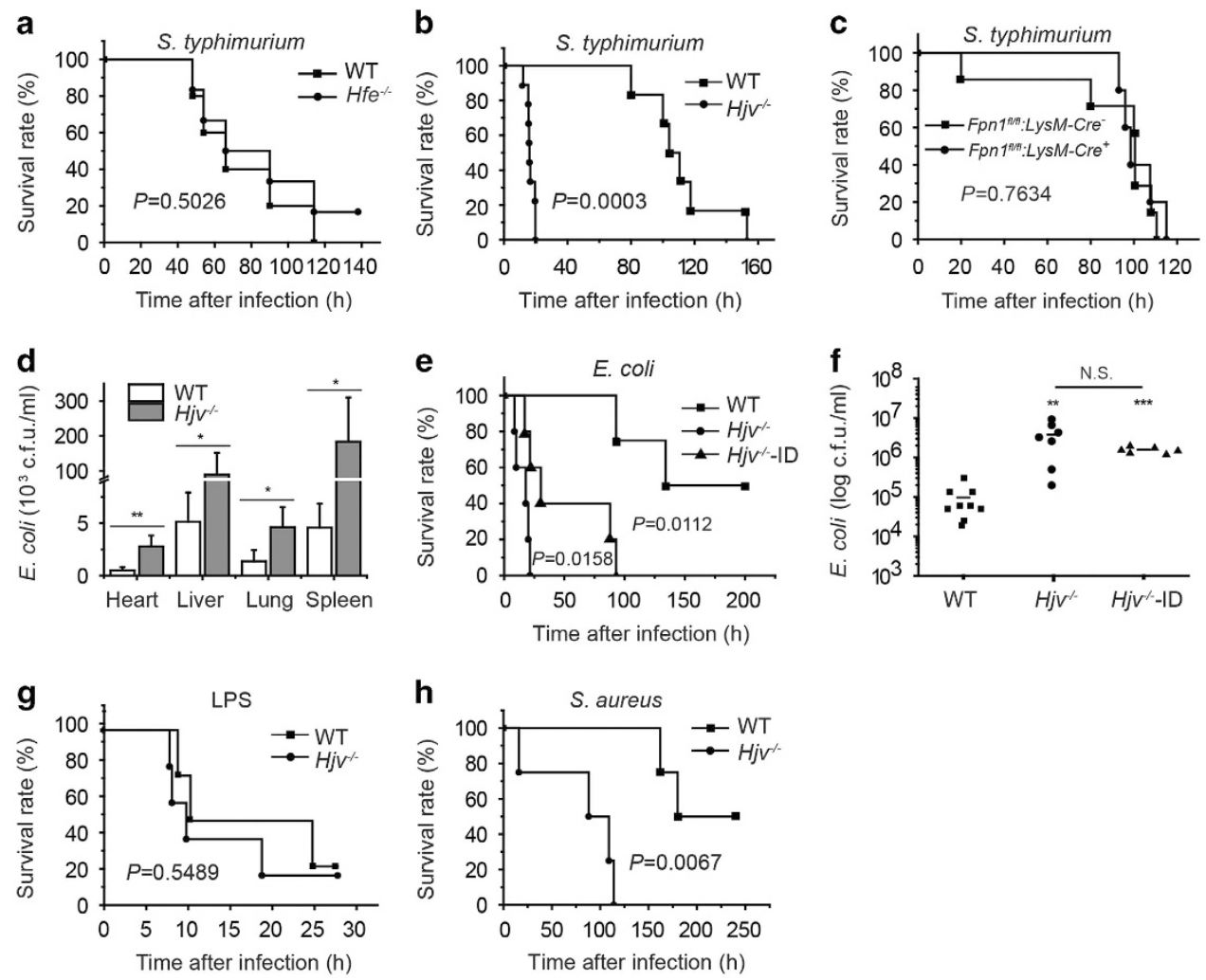

Figure $1 \mathrm{Hjv}$ confers protection against Gram-positive and Gram-negative bacterial infections. (a-c) $\mathrm{Hfe}^{-/-}(\mathbf{a}), \mathrm{Hjv}^{-/-}$(b), and

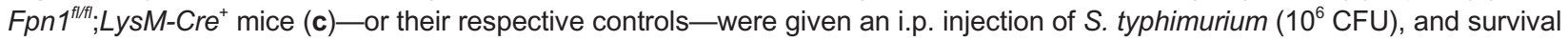
was plotted using a Kaplan-Meier curve. $N=5-8$ mice/group. (d) Bacterial CFU values were measured in the heart, liver, spleen, and lung tissues of $\mathrm{Hjv}^{-/-}$and wild-type mice $12 \mathrm{~h}$ after an i.p. injection of Escherichia coli. ${ }^{*} P<0.05,{ }^{* *} P<0.01$. N $\geq 5$ samples/ group. (e) Kaplan-Meier survival curve of wild-type, $\mathrm{Hjv}^{-/}$, and iron-deficient $\mathrm{Hjv}^{-/}\left(\mathrm{Hjv}^{-/}-\mathrm{ID}\right)$ mice following an i.p. injection of E. coli $\left(2 \times 10^{8} \mathrm{CFU}\right) . N=6$ mice/group. (f) Bacterial CFUs were measured in the peritoneal fluid of wild-type, $\mathrm{Hjv}^{-/-}$, and $\mathrm{Hjv}^{-/-}$-ID mice $12 \mathrm{~h}$ after an i.p. injection of $E$. coli $\left(2 \times 10^{8} \mathrm{CFU}\right) .{ }^{* *} P<0.01$ vs wild type, ${ }^{* * *} P<0.001$ vs wild type, NS stands for not significant. Each data point represents an individual animal. $(\mathbf{g}, \mathbf{h})$ Kaplan-Meier survival curves of $\mathrm{Hjv}^{-/-}$and wild-type mice following an i.p. injection of LPS $\left(0.1 \mu \mathrm{g}\right.$ per mouse) and D-galactosamine $\left(0.5 \mathrm{mg} \mathrm{g}^{-1}\right.$ body weight) $(\mathbf{g})$, or $\mathrm{S}$. aureus (10 $\left.{ }^{8} \mathrm{CFU}\right)$ (h). $N=6$ mice per group.

Based on these findings, we hypothesized that the local defense process is impaired in the peritoneal cavity of $\mathrm{Hjv}^{-/-}$mice. We therefore measured the immune response in the peritoneal cavity following bacterial infection. In the early stages of bacterial infection, macrophages and neutrophils mediate bacterial clearance [24]. To determine the relative proportions of these two cell types in infected $\mathrm{Hjv}^{-/-}$ mice, we isolated peritoneal cells, stained the cells with F4/80 and Gr-1, and performed flow cytometry [25]. Our analysis revealed that $6-12 \mathrm{~h}$ after bacterial infection, neutrophils $\left(\mathrm{F} 4 / 80^{-}, \mathrm{Gr}-1^{+}\right)$and macrophages $\left(\mathrm{F} 4 / 80^{+}\right)$comprised $\sim 80 \%$ and $10 \%$, respectively, of the total population of phagocytes; after $24 \mathrm{~h}$, the percentage of neutrophils decreased to $\sim 50 \%$, and the percentage of macrophages increased to $\sim 40 \%$ (Figure 2b). Interestingly, the relative proportions of both cell types were similar between $\mathrm{Hjv}^{-/-}$and wildtype mice following bacterial infection, indicating that the migration of macrophages and neutrophils to the peritoneal cavity is intact in $\mathrm{Hjv}^{-/-}$mice.

Next, we examined further the phagocytic function of peritoneal cells. Primary peritoneal macrophages were obtained from $\mathrm{Hjv}^{-/-}$and wild-type mice by peritoneal lavage with Thioglycollate medium [26]. We then incubated the cells with Alexa Fluor 488 conjugated heat-killed E. coli and measured phagocytosis using flow cytometry. We found no difference between $\mathrm{Hjv}^{-1-}$ macrophages and wild-type macrophages with respect to phagocytosis ratio (Figure 2c) or mean fluorescence intensity (Figure 2d), suggesting that $\mathrm{Hjv}^{-1-}$ macrophages have normal phagocytic activity. Despite normal phagocytosis measured in vitro, we observed more GFP fluorescence in peritoneal cells 
obtained from $\mathrm{Hjv}^{-/-}$mice $12 \mathrm{~h}$ after infection with GFP-expressing E. coli compared with wild-type mice (Figure 2e). This stronger immune response in $\mathrm{Hjv}^{-/}$ mice may be due to bacterial overload in the phagocytes; on the other hand, bacteria in the peritoneal cavity were over-proliferated in $\mathrm{Hjv}^{-/-}$mice (Figure 1f). Taken together, these data suggest that although more bacteria are engulfed by $\mathrm{Hjv}^{-/-}$

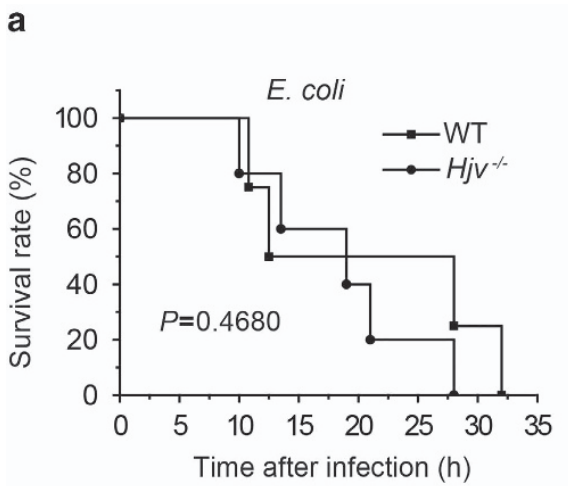

b

C
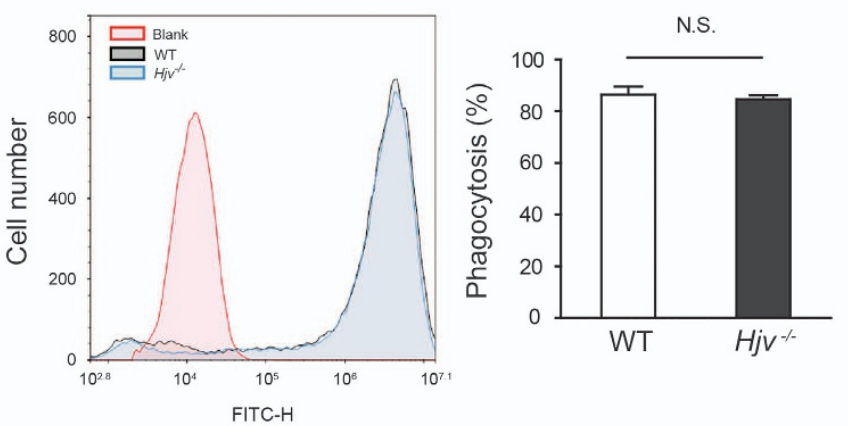

E. coli $12 \mathrm{~h} \quad$ E. coli $24 \mathrm{~h}$

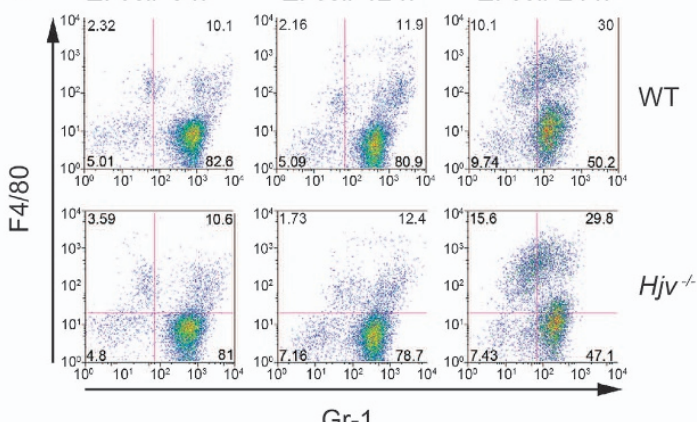

Gr-1

d
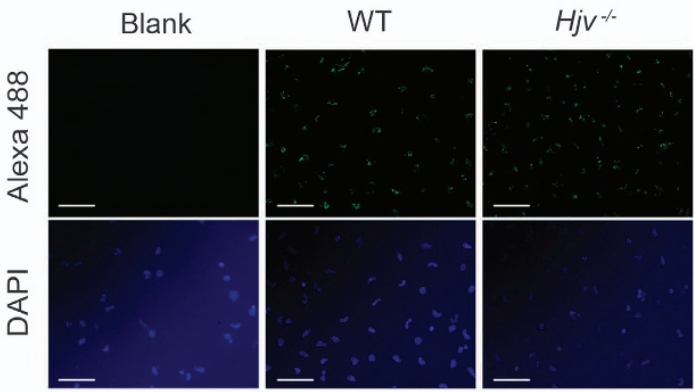

e
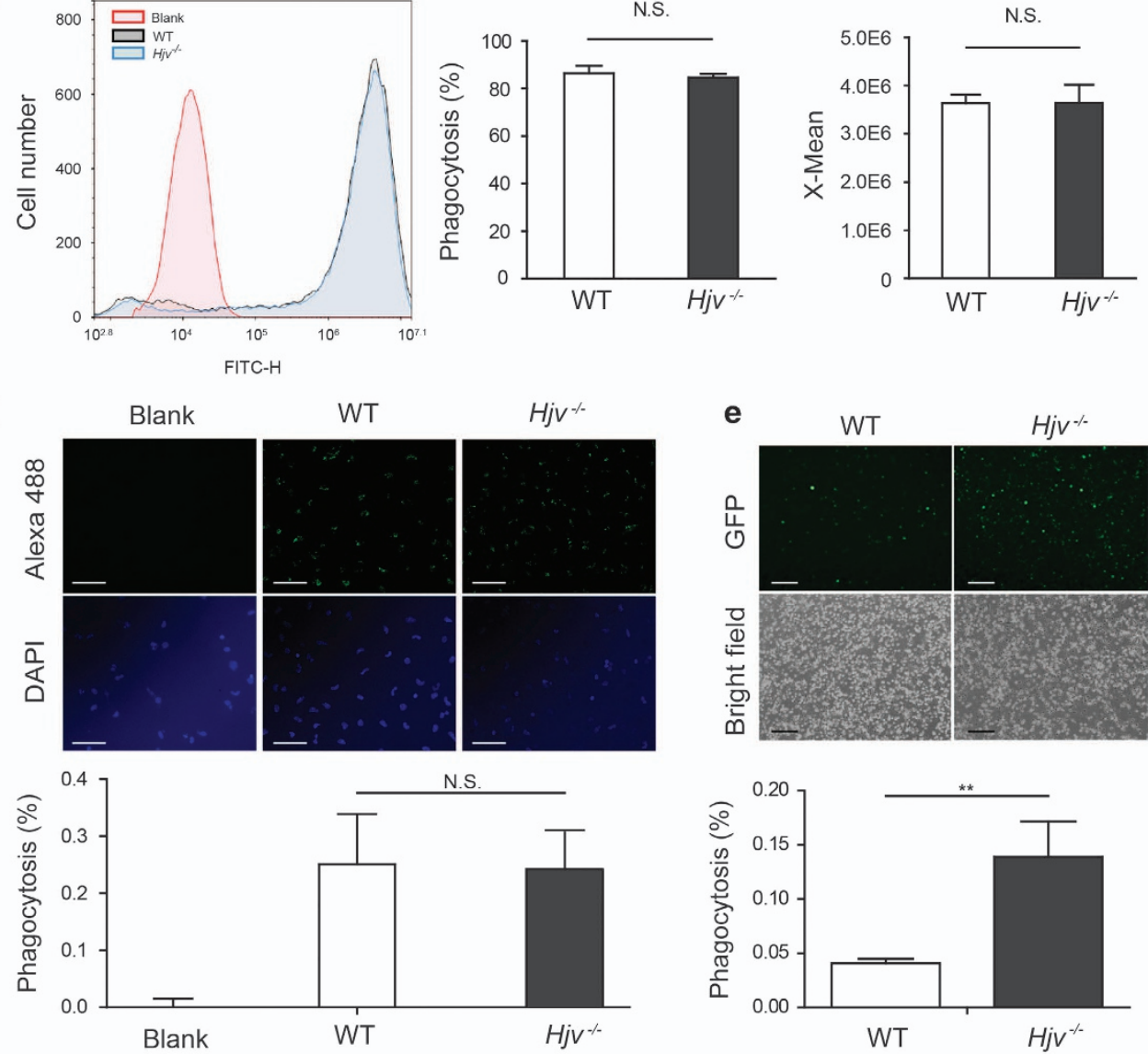

Figure $2 \mathrm{Hjv}$ plays a role in the intracellular pathogen killing capacity of peritoneal cells. (a) Kaplan-Meier survival curve of $\mathrm{Hjv}^{-/-}$ and wild-type mice following an i.v. injection of $E$. coli $\left(2 \times 10^{8} \mathrm{CFU}\right) . N=6$ mice per group. (b) Flow cytometry analysis of macrophages and neutrophils (stained for the markers $\mathrm{F} 4 / 80$ and $\mathrm{Gr}-1$, respectively) isolated from wild-type and $\mathrm{Hjv}^{-/-}$mice at the indicated times following an i.p. injection of E. coli. (c, d) Macrophages were incubated with Alexa Fluor 488-conjugated heatkilled E. coli for $1 \mathrm{~h}$, quenched, washed, and analyzed for phagocytosis rate using flow cytometry (c) and fluorescence microscopy (d). 'X-mean' indicates mean fluorescence intensity (c). Scale bar represents $500 \mu \mathrm{m}$ (d). (e) Representative images of peritoneal cells isolated from wild-type and $\mathrm{Hjv}^{-/-}$mice $12 \mathrm{~h}$ after infection with a TOP10 E. coli strain expressing GFP; the scale bar represents $100 \mu \mathrm{m} .{ }^{* *} P<0.01$. N.S. stands for not significant. 
phagocytes, they are not efficiently killed and/or degraded.

\section{Reduced IFN- $\gamma$ expression in $\mathrm{Hj}^{-/-}$neutrophils and macrophages}

To test for a possible immune deficiency in $\mathrm{Hjv}^{-/-}$ mice, we measured the levels of circulating inflammatory cytokines, which generally reflect the presence of an ongoing immune response and can be used to monitor bacteria clearance. We therefore collected serum samples after infecting mice with of $E$. coli $\left(2 \times 10^{8} \mathrm{CFU}\right)$ by i.p. injection; serum was collected 1 , 2.5 , and $6 \mathrm{~h}$ after infection for measuring TNF- $\alpha$, IL-6 and IFN- $\gamma$ levels, respectively. Both TNF- $\alpha$ and IL-6 levels were approximately twofold higher in the serum of $\mathrm{Hjv}^{-I-}$ mice compared with wild-type mice; in contrast, IFN- $\gamma$ levels were significantly lower in the $\mathrm{Hjv}^{-1-}$ mice (Figure 3a).

IFN- $\gamma$ is secreted primarily by NK (natural killer) cells and T cells [27]. However, in our acute infection models, the mice died within $24 \mathrm{~h}$, well before NK cells and $\mathrm{T}$ cells are activated [27]. We first confirmed that splenocytes isolated from infected $\mathrm{Hjv}^{-1-}$ mice and wild-type mice have extremely low IFN- $\gamma$ secretion (Supplementary Figure S3A). We then examined several cell types in the peritoneal cavity. Macrophages and neutrophils are potential sources of IFN- $\gamma$ in the early stage of infection $[28,29]$. Thus, a lack of IFN- $\gamma$ autocrine secretion may underlie the impaired killing capacity of $\mathrm{Hjv}^{-1-}$ macrophages and neutrophils. Indeed, the myeloid lineage cell fraction in the peritoneal cavity contained considerable numbers of IFN- $\gamma$ positive (IFN- $\gamma^{+}$) cells (Figure $3 b$ ). Six hours after E. coli infection, 17.5 and $4 \%$ of wild-type and $\mathrm{Hjv}^{-/-}$ peritoneal myeloid lineage cells were IFN- $\gamma^{+}$ (Figure 3b). Twelve hours after infection, the percentage of IFN- $\gamma^{+}$cells decreased in both genotypes; however, the percentage of IFN- $\gamma^{+}$cell was still 2 -fold higher in the wild-type mice than in the $\mathrm{Hjv}^{-1-}$ mice. We then examined the identity of the IFN- $\gamma^{+}$cells 6,12 , and $24 \mathrm{~h}$ after infection. For wild-type peritoneal cells, $6 \mathrm{~h}$ after infection, $75 \%$ and $25 \%$ of the IFN- $\gamma^{+}$cells were neutrophils (that is, $\mathrm{Gr}-1^{+}, \mathrm{F} 4 / 80^{-}$cells) and macrophages (that is, F4/80 cells), respectively; however, $12 \mathrm{~h}$ after infection, the percentage of IFN- $\gamma^{+}$ neutrophils cells decreased to only $13 \%$, and the percentage of macrophages increased to $87 \%$. Moreover, in wild-type mice we detected only a very small proportion of $\mathrm{T}$ cells $\left(\mathrm{CD} 8 \mathrm{~b}^{+}\right)$and $\mathrm{NK}$ cells $\left(\mathrm{NK} 1.1^{+}\right)$ within the peritoneal population of IFN- $\gamma^{+}$cells $12 \mathrm{~h}$ after infection (Supplementary Figure S3B); thus, phagocytes - rather than NK cells or T cells - are the principal source of IFN- $\gamma$ in the early stages of peritoneal infection.

Recent studies found that cellular iron content can affect macrophage function [19, 30]. In $\mathrm{Hjv}^{-/-}$mice, splenic iron content is low (Supplementary Figure S1A) because ferroportin retained in the plasma membrane exports more iron out of these macrophages in the spleen. To exclude this effect, we generated macrophage-specific $\mathrm{Hj} v$-knockout $\left(\mathrm{Hj}^{f l l f} ; \mathrm{Lys} \mathrm{M}-\mathrm{Cre}^{+}\right)$ mice; iron content in the major organs and macrophages of these mice was normal (Supplementary Figure $\mathrm{S} 1 \mathrm{~B}$ and D), and E. coli-induced mortality was similar between $\mathrm{Hjv}^{\text {flffl }}$; $\mathrm{LysM}-\mathrm{Cre}^{+}$mice and $\mathrm{Hjv}^{-1-}$-ID mice (compare Figure 3c with Figure 1e). Notably, treating $\mathrm{Hjv}^{\text {fllf }} ; \mathrm{LysM}-\mathrm{Cre}^{+}$mice with IFN- $\gamma$ (10 units per mouse) [31, 32 ] significantly improved survival following E. coli infection (Figure 3d).

Next, we examined the specific functions of macrophages and neutrophils. We performed adoptive transfer experiments by injecting $2 \times 10^{6}$ wild-type neutrophils or macrophages into the peritoneal cavity of $\mathrm{Hjv}^{-1-}$ mice; $4 \mathrm{~h}$ later, these mice were challenged with a lethal dose of E. coli $\left(2 \times 10^{8} \mathrm{CFU}\right)$. Although transferring wild-type neutrophils conferred no protection to these mice (Figure 3e), transferring wild-type macrophages conferred a significant protective effect against bacterial infection compared with $\mathrm{Hjv}^{-1-}$ macrophages (Figure 3f). Thus, impaired macrophage function, possibly due to reduced IFN- $\gamma$ production and/or secretion, appears to play a key role in the susceptibility of $\mathrm{Hjv}^{-/-}$mice to bacterial infection.

\section{Decreased IFN- $\gamma$ secretion in $\mathrm{Hj}^{{ }^{-l-}}$ macrophages} reduces their nitric oxide production and killing capacity

IFN- $\gamma$ is a critical mediator of protective immunity against both viral and bacterial infections; consistent with this role, $I F N-\gamma$-knockout mice are highly susceptible to bacterial infection [33, 34]. Specifically, peritoneal cells produce IFN- $\gamma$ and are essential for the survival of infected mice, and bacterial clearance by these cells is impaired when IFN- $\gamma$ secretion is reduced [35]. To further investigate the function of IFN- $\gamma$ release by macrophages in the early stages of bacterial infection, we isolated and cultured peritoneal macrophages, then stimulated the cells with $E$. coli that was heat-killed to prevent lethality due to uncontrolled bacterial replication, thereby mimicking infection in vivo. Twenty-four hours after stimulation, both $\mathrm{Hjv}^{--}$and $\mathrm{Hjv}^{\text {fllfl}}$; LysM-Cre ${ }^{+}$macrophages secreted significantly fewer amounts of IFN- $\gamma$ compared with wild-type macrophages (Figure 4a); in contrast, both TNF- $\alpha$ and IL- 6 were produced at wild-type levels 
(Supplementary Figure S4A and B). In macrophages, IFN- $\gamma$ activates the enzyme iNOS (inducible nitric oxide synthase), thereby increasing nitric oxide (NO) production in these cells [36, 37]. We used thioglycollate-elicited macrophages as our primary cell model, as NO synthesis is robust in these cells [38, 39]. After cells were stimulated with heat-killed E. coli, both phosphorylated Stat1 (pStat1, an upstream activator of a

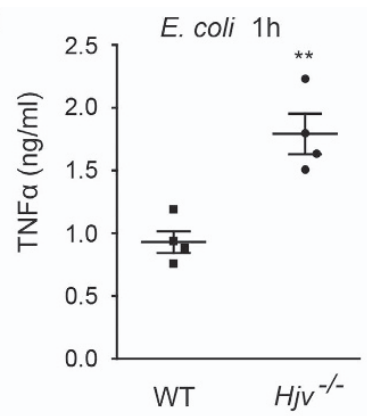

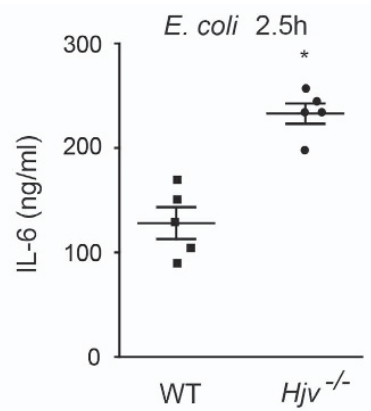

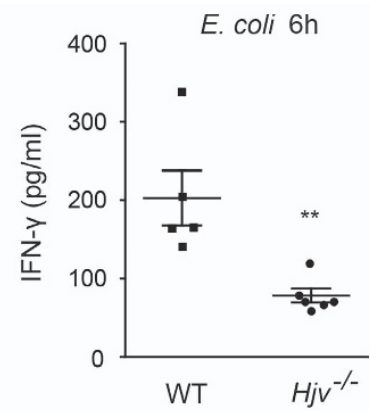

b

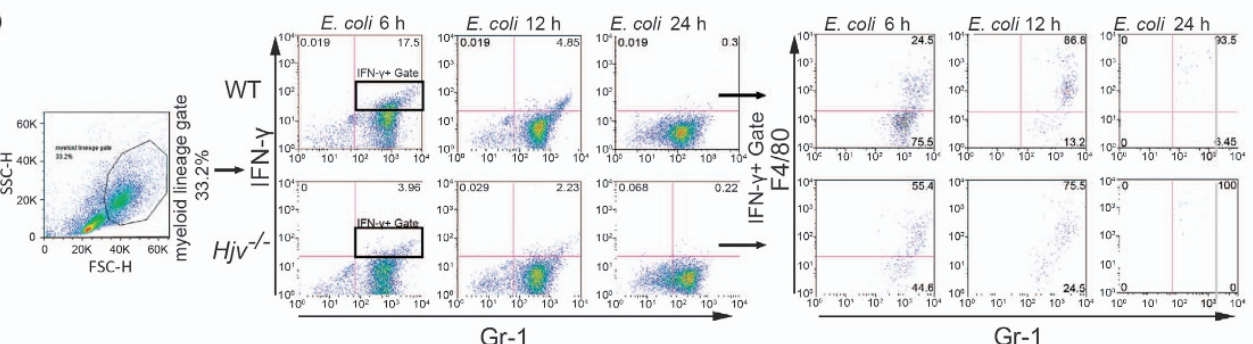

C

c
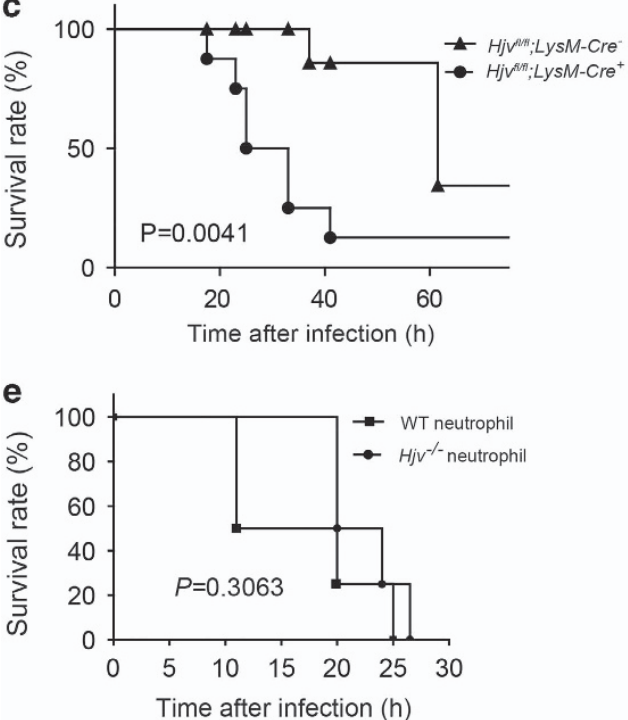

d
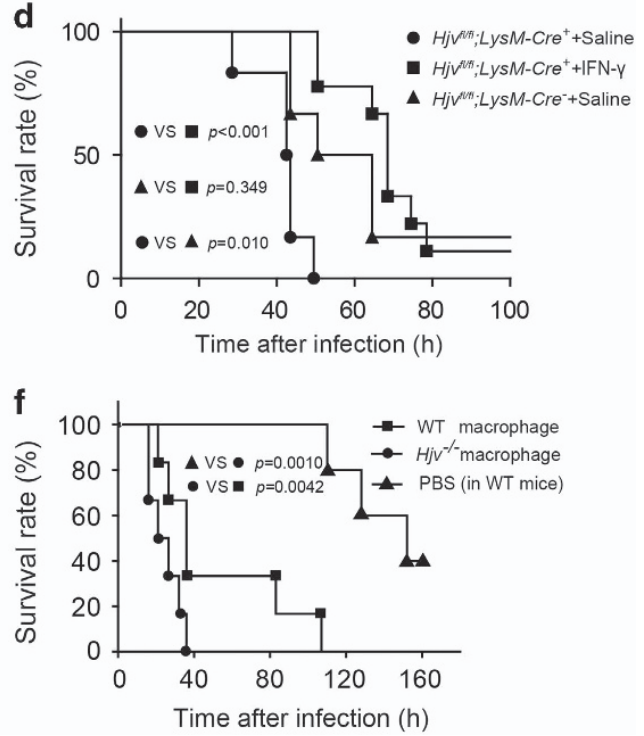

Figure $3 \mathrm{Hjv}$ is required for IFN- $\gamma$ secretion. (a) TNF- $\alpha$, IL-6, and IFN- $\gamma$ concentrations were measured in serum samples from wild-type and $\mathrm{Hjv}^{-/-}$mice $1 \mathrm{~h}(N=4 /$ group $), 2.5 \mathrm{~h}(N=5 /$ group $)$, and $6 \mathrm{~h}(N=4-6$ per group) after an i.p. injection of $E$. coli $\left(2 \times 10^{8} \mathrm{CFU}\right) .{ }^{*} P<0.05$ vs wild type, ${ }^{* *} P<0.01$ vs wild type. (b) Peritoneal cells were obtained from wild-type and $H_{j j v^{-/-}}$mice following an i.p. injection of $E$. coli. The cells were then stained for $\mathrm{Gr}-1, \mathrm{~F} 4 / 80$, and IFN- $\gamma$ and analyzed using flow cytometry. (c) Kaplan-Meier survival curve of $\mathrm{Hjv}^{f / f /} ; \mathrm{LysM}-\mathrm{Cre}^{+}$and $\mathrm{Hjv}^{f / / f l} ; \mathrm{LysM}-\mathrm{Cre}{ }^{-}$mice $(\mathrm{N}=6-7$ per group) following an i.p. injection of

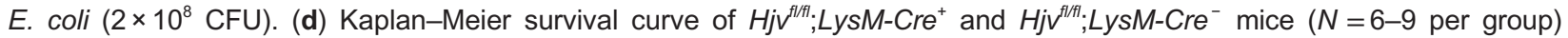
following a subcutaneous injection of 10 units IFN- $\gamma$ in saline (or saline alone) followed immediately by an i.p. injection of TOP10 E. coli $\left(2 \times 10^{8} \mathrm{CFU}\right)$. (e) Rescue (adoptive transfer) experiment in which $\mathrm{Hjv}^{-/}$mice received an injection of either $2 \times 10^{6}$ wild-type neutrophils or $2 \times 10^{6} \mathrm{Hjv}^{-/-}$neutrophils; four hours later, the mice were given an i.p. injection of $\mathrm{E}$. coli $\left(2 \times 10^{8} \mathrm{CFU}\right)$. (f) Rescue (adoptive transfer) experiments in which $\mathrm{Hjv}^{-/-}$mice received an injection of either $2 \times 10^{6}$ wild-type macrophages or $2 \times 10^{6} \mathrm{Hjv}^{-1-}$ macrophages; four hours later, the mice were given an i.p. injection of $E$. coli $\left(2 \times 10^{8} \mathrm{CFU}\right)$. For comparison, wild-type mice were injected with PBS followed by an i.p. injection of $E$. coli $\left(2 \times 10^{8} \mathrm{CFU}\right)$. ${ }^{* *} P<0.01$. NS stands for not significant. 


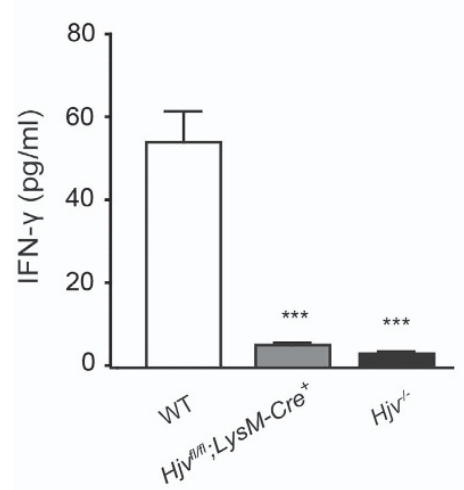

d
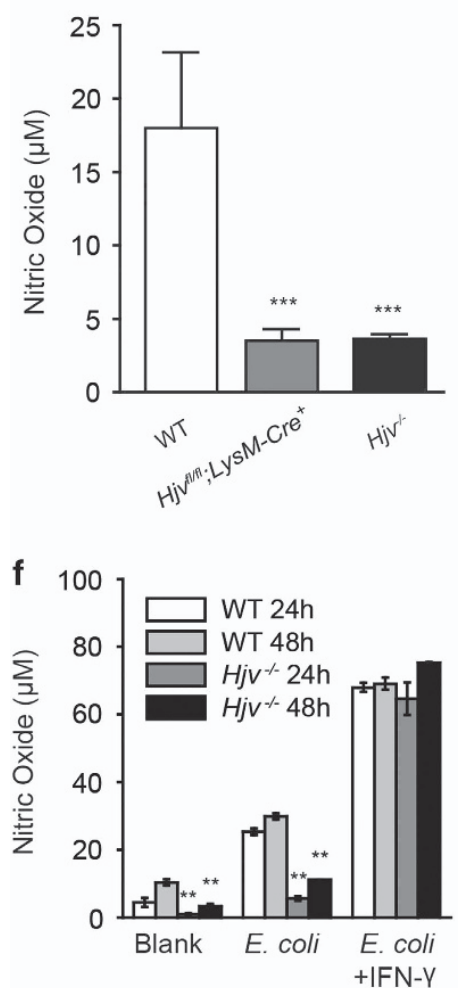

b
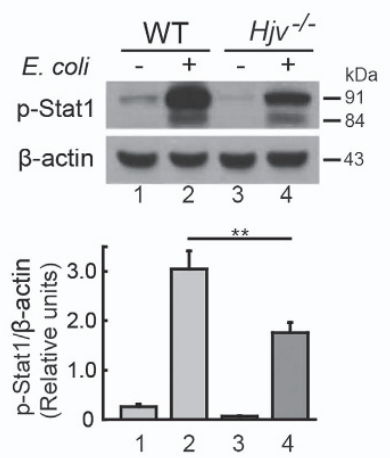

e
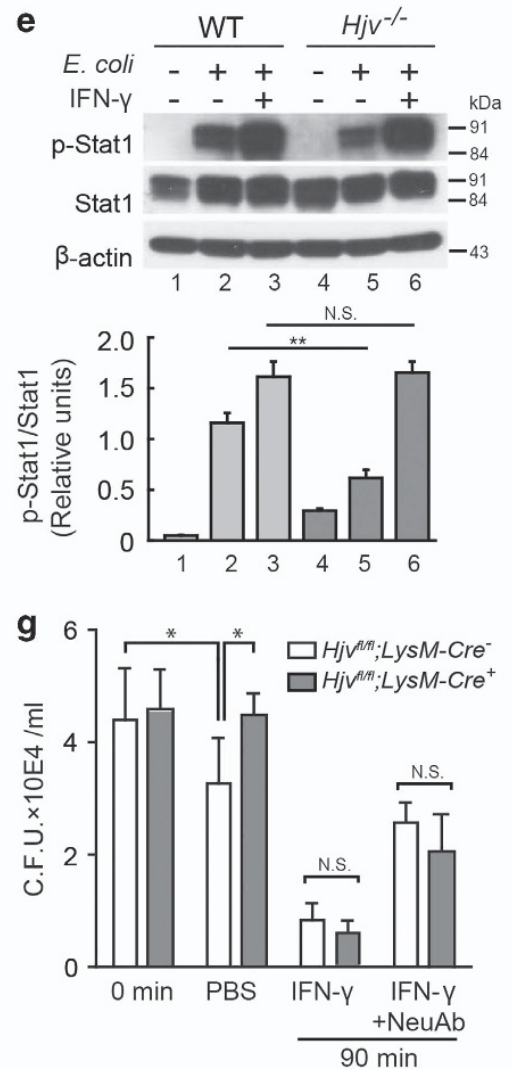

C
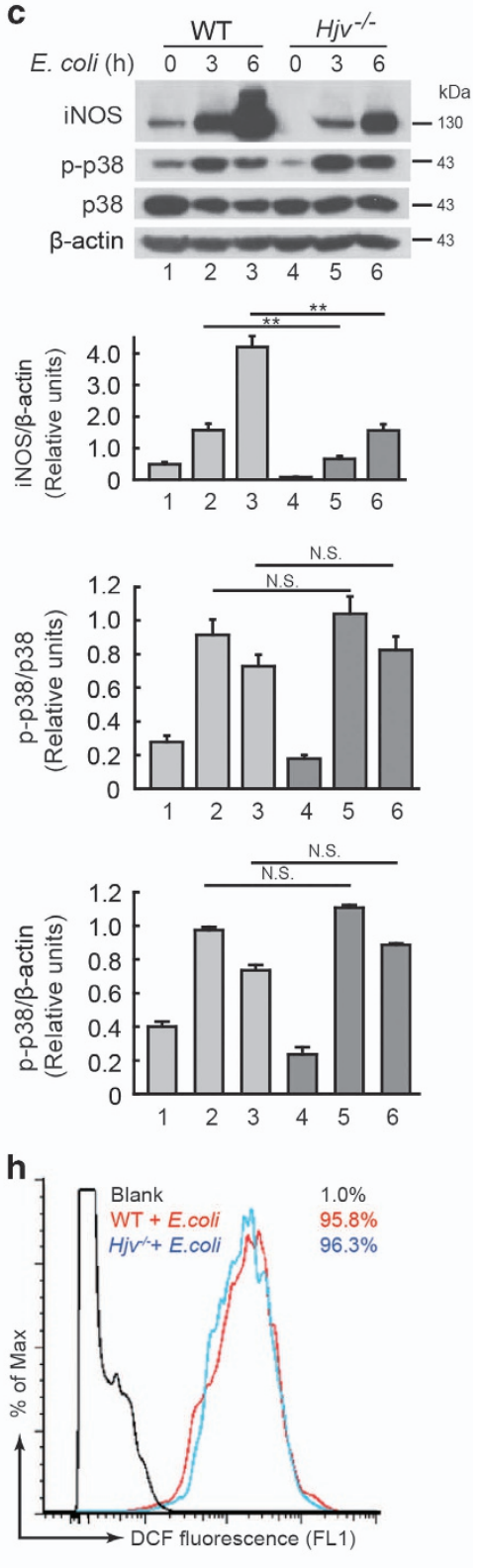

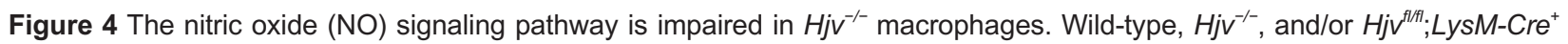
macrophages were stimulated in vitro with heat-killed $E$. coli, and downstream NO signaling was examined. (a) IFN- $\gamma$ secretion was measured in the supernatant of cultured macrophages $24 \mathrm{~h}$ after stimulation with heat-killed $E$. coli. ${ }^{* * *} P<0.001$ vs wild type; $N=3$ per group. (b, c) Western blot analyses of pStat1, iNOS, p-p38, and p38 in cells with or without E. coli stimulation; pStat 1 and iNOS levels were normalized to $\beta$-actin, and p-p38 was normalized to p38. (d) NO was measured using the Griess assay from culture medium collected $24 \mathrm{~h}$ after cells were stimulated with heat-killed $E$. coli. ${ }^{* * *} P<0.001$ vs wild type; $N=3$ per group. (e) Treating cells with exogenous IFN- $\gamma$ restored Stat1 phosphorylation in $\mathrm{Hjv}^{-/-}$macrophages; pStat1 levels were normalized to $\beta$-actin. (f) Treating cells with IFN- $\gamma$ restored NO production in $\mathrm{Hjv}^{-/-}$macrophages. NO was measured using the Griess assay in cell culture medium collected 24 and $48 \mathrm{~h}$ after stimulation with heat-killed $\mathrm{E}$. coli. $N=3$ per group. (g) Cytolytic capacity of $\mathrm{Hjv}^{\mathrm{f} / \mathrm{fl} \text {; }}$ LysM-Cre ${ }^{-}$and $\mathrm{Hjv}^{f / f i} ; \mathrm{LysM}-\mathrm{Cre}^{+}$macrophages following stimulation with $\mathrm{E}$. coli. At the indicated time points, the cells were lysed, and bacterial viability was measured; where indicated, cells were pretreated with PBS, $100 \mathrm{ng} \mathrm{ml}^{-1} \mathrm{IFN}-\gamma$, and/or $20 \mathrm{ng} \mathrm{ml}{ }^{-1}$ of the IFN- $\gamma$ neutralizing antibody (NeuAb) $12 \mathrm{~h}$ before stimulation. ${ }^{*} P<0.05$ vs the 0 -min wild-type group. $N=3$ per group. (h) ROS levels were measured in wild-type and $\mathrm{Hjv}^{-/-}$macrophages $1 \mathrm{~h}$ after stimulation with heat-killed $\mathrm{E}$. coli. NS stands for not significant. 
iNOS) and iNOS expression were significantly lower in $\mathrm{Hjv}^{-1-}$ macrophages compared with wild-type cells (Figure $4 \mathrm{~b}$ and $\mathrm{c}$ ). Moreover, the amount of NO released was significantly lower in both $\mathrm{Hjv}^{-/-}$and $\mathrm{Hjv}^{\text {fll }}$ ${ }^{f}$; Lys M-Cre ${ }^{+}$macrophages compared with wild-type cells (Figure 4d). Applying exogenous IFN- $\gamma$ $\left(100 \mathrm{ng} \mathrm{ml}^{-1}\right)$ to $\mathrm{Hjv}^{-/-}$macrophages restored both their pStatl levels and NO secretion (Figure 4e and f). Macrophages utilize NO production to confer protection from invading pathogens [40]. We, therefore, collected thioglycollate-elicited macrophages from both

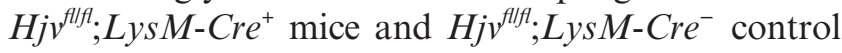
mice. After $90 \mathrm{~min}$ in culture, the bacterial killing capacity of the $\mathrm{Hjv}^{\text {fllfl }}$; LysM-Cre $\mathrm{CH}^{+}$macrophages was significantly decreased compared with $\mathrm{Hjv}^{\text {fllfl }} ; \mathrm{LysM}$ $\mathrm{Cre}^{-}$controls (that is, the $\mathrm{Hjv}^{\mathrm{flff}} ; \mathrm{LysM}$ - $\mathrm{Cre}^{+}$macrophages contained significantly more CFUs than the control cells) (Figure 4g). Notably, pretreating both $\mathrm{Hjv}^{\text {fllff }}$; Lys M-Cre ${ }^{+}$and control macrophages with IFN- $\gamma$ significantly increased bacterial killing capacity, thereby rescuing the phenotype in $\mathrm{Hjv}^{\text {fllfl }} ; \mathrm{LysM}$-Cre ${ }^{+}$ macrophages. Moreover, co-treating cells with IFN- $\gamma$ and an IFN- $\gamma$ neutralizing antibody (NeuAb) significantly reduced the bacterial killing capacity of both $\mathrm{Hjv}^{\text {fllfl}}$; Lys M-Cre ${ }^{+}$and control macrophages (Figure 4g).

To investigate other possible mechanisms involved in the killing capacity of macrophages, we also measured the level of reactive oxygen species (ROS) within the cells. However, we found no significant difference between $\mathrm{Hjv}^{-/-}$and wild-type macrophages (Figure 4h). We therefore conclude that impaired IFN- $\gamma$ production in $\mathrm{Hjv}^{-1-}$ macrophages plays a principal role in the reduced killing capacity of these cells, possibly explaining the unrestricted growth of bacteria in the peritoneal cavity and major organs of $\mathrm{Hjv}^{-1-}$ mice.

\section{Hjv is upregulated and facilitates the NO cascade in infected macrophages}

We found that elicited wild-type macrophages treated with heat-killed $E$. coli had significantly increased levels of $H j v$ mRNA (Figure 5a); in contrast, and

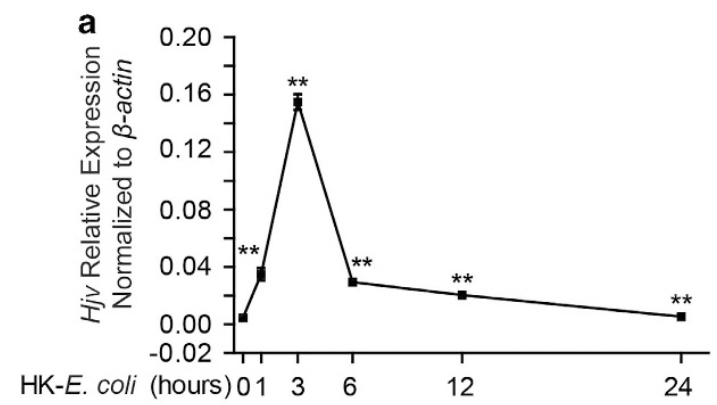

c
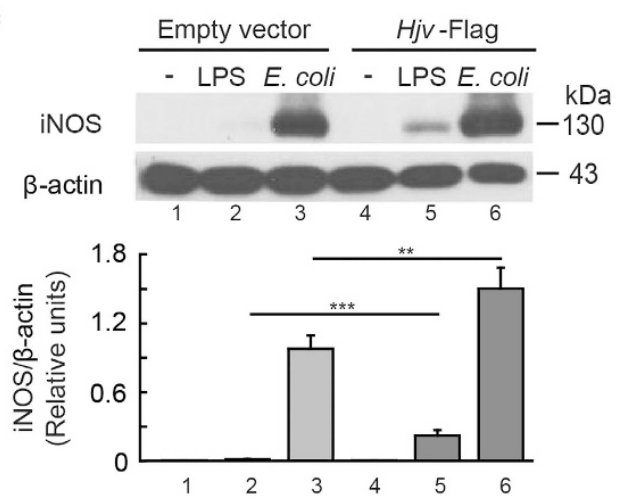

b

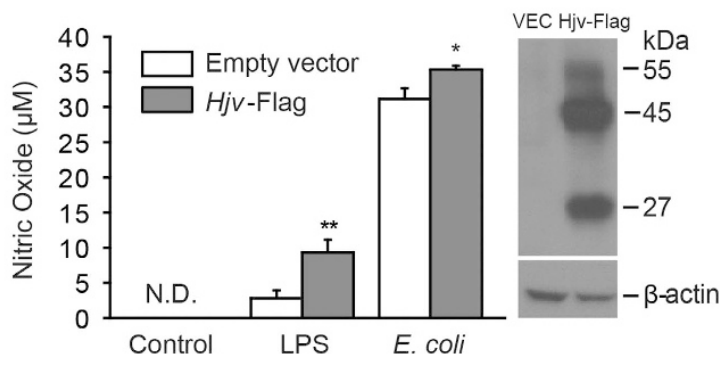

d
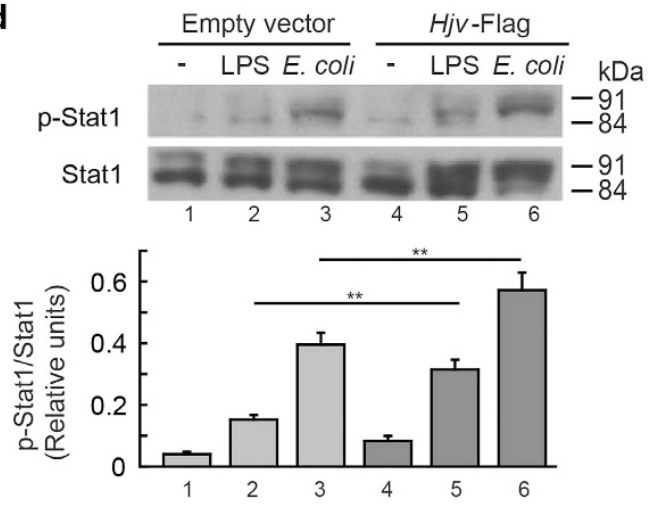

Figure 5 Hjv expression is upregulated in macrophages following stimulation with heat-killed $E$. coli, and Hjv expression facilitates iNOS signaling in vitro. (a) Hjv mRNA was measured in macrophages 0, 1, 3, 6, 12 and $24 \mathrm{~h}$ after stimulation with heat-killed E. coli $\left(10^{8} \mathrm{CFU}\right)$ and is expressed normalized to $\beta$-actin mRNA, ${ }^{* *} P<0.01$ vs the 0 -h WT Hjv mRNA level. (b) NO was measured using the Griess assay in the culture medium of RAW264.7 cells transfected with HJV-Flag or empty vector (VEC), then stimulated for $24 \mathrm{~h}$ with LPS $\left(100 \mathrm{ng} \mathrm{ml}^{-1}\right)$ or heat-killed $E$. coli $\left(10^{8} \mathrm{CFU}\right)$. ${ }^{*} P<0.05$ vs empty vector, ${ }^{* *} P<0.01$ vs empty vector. Right panel: western blot of the expression of Flag-tagged HJV protein in RAW264.7 cells. (c, d) Western blot analysis of iNOS (c) and pStat1 (d) in RAW264.7 cells transfected with HJV-Flag or empty vector, and then stimulated for $24 \mathrm{~h}$ with LPS or heat-killed E. coli. Protein expression levels were normalized to $\beta$-actin (c) or Stat1 (d). N.S. stands for not significant. 
consistent with a previous report [7], Hjv expression was decreased in the liver (Supplementary Figure S5). These results suggest that Hjv may play a regulatory role during infection. Interestingly, stimulating $\mathrm{Hjv}$ transfected RAW264.7 cells (a murine macrophage cell line) with either LPS or heat-killed E. coli led to significantly increased NO production compared with control cells and cells transfected with an empty vector (Figure 5b). Consistent with these results, both iNOS expression (Figure 5c) and pStat1 levels (Figure 5d) were also increased. These results suggest that Hjv plays a key role in both iNOS expression and NO production in macrophages. Given that IFN- $\gamma$ treatment rescued iNOS signaling (Figure 4e, f), Hjv likely modulates the iNOS cascade primarily via IFN- $\gamma$ signaling.

\section{IL-12/Stat4 signaling is impaired in $\mathrm{Hjv}^{-/-}$macrophages}

$\mathrm{Hjv}$ is a major regulator of $\mathrm{Bmp} / \mathrm{Smad}$ signaling [41]. However, whether $\mathrm{Bmp} / \mathrm{Smad}$ signaling is altered in $\mathrm{Hjv}^{-/-}$macrophages and/or whether crosstalk exists between the inflammatory response and $\mathrm{Bmp} / \mathrm{Smad}$ signaling is not currently known. Bmp6 can induce NO production in macrophages independent of Smad [42], and inflammatory stimuli can reduce Smad1/5/8 phosphorylation in macrophages [43]. However, we found similar levels of phosphorylated Smad1/5/8 levels between $\mathrm{Hjv}^{--}$and wild-type macrophages following stimulation with heat-killed E. coli (Supplementary Figure S6A). When we treated wildtype macrophages with LDN193189, a classic inhibitor of Bmp/Smad signaling, [44] pSmad1/5/8 levels were significantly reduced (Supplementary Figure S6A), whereas iNOS expression was increased (Supplementary Figure S6B). Moreover, the effect of heat-killed E. coli on Bmp/Smad signaling was unaffected by Hjv deletion (Supplementary Figure S6A). Together, these results indicate that $\mathrm{Bmp} / \mathrm{Smad}$ signaling is likely not altered in $\mathrm{Hjv}^{-1-}$ macrophages during bacterial infection.

Both IL-18 [45] and IL-12 [46] are key regulators of IFN- $\gamma$ secretion. Therefore, to investigate the possible mechanism by which $\mathrm{Hjv}$ regulates IFN- $\gamma$, we collected serum from $\mathrm{Hjv}^{-1-}$ and wild-type mice following $\mathrm{E}$. coli infection. We found no significant difference between

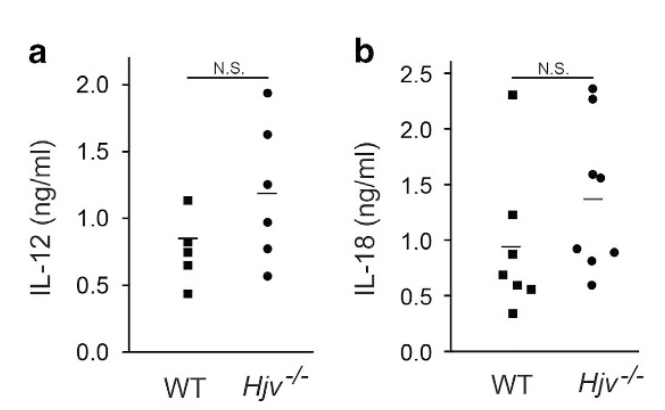

d

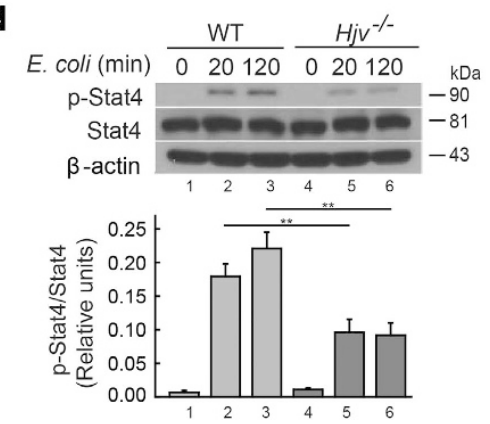

e
C
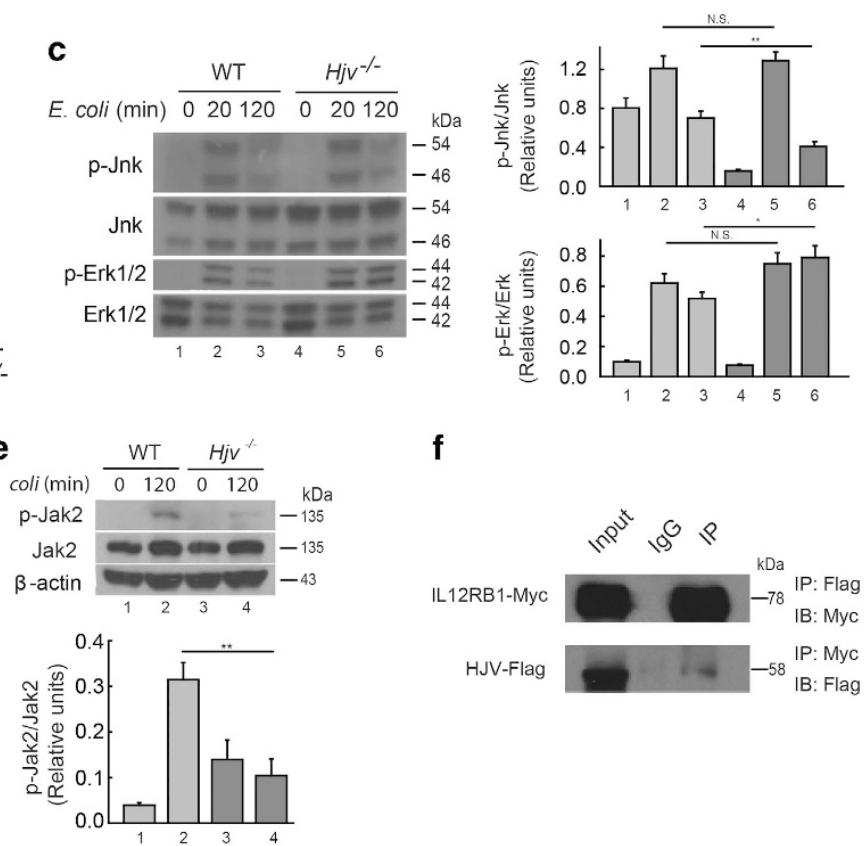

f

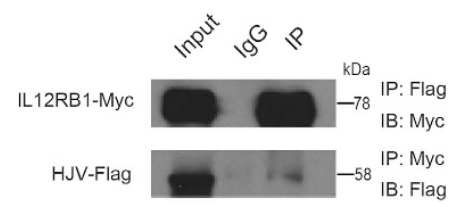

Figure 6 Hjv plays a role in IL-12/Stat4 signaling. (a, b) Serum IL-12 and IL-18 levels were measured in wild-type and Hjv $^{-/-}$mice $2.5 \mathrm{~h}(\mathbf{a})$ and $6 \mathrm{~h}(\mathbf{b})$ after an i.p. injection of $E$. coli $\left(10^{8} \mathrm{CFU}\right) . \mathrm{N}=6-8$ mice per group. (c-e) Western blot analysis of pErk1/2, Erk1/2, pJnk, and Jnk (c), pStat4 and Stat4 (d), and pJak2 and Jak2 (e) at the indicated times in macrophages following in vitro stimulation with heat-killed E. coli $\left(10^{8} \mathrm{CFU}\right)$. Each phosphorylated protein band was normalized to its respective total protein band. (f) Reciprocal co-immunoprecipitation experiments were performed using HEK392 cells co-transfected with Flag-tagged HJV (HJV-Flag) and Myc-tagged IL-12RB1 (IL-12RB1-Myc). In the upper panel, an anti-FLAG antibody was used to pull down (IP) HJV-Flag in whole cell lysates, followed by western blotting (IB) with anti-Myc. In the lower panel, the anti-Myc antibody was used to pull down IL-12RB1-Myc, followed by western blotting with anti-Flag. 'Input' is equivalent to $6 \%$ of the lysate used for the pull down, and 'IgG' refers to pull down using a control lgG as a negative control. ${ }^{* *} P<0.01$. NS stands for not significant. 
$\mathrm{Hjv}^{-/-}$and wild-type mice with respect to either IL-12 (Figure 6a) or IL-18 (Figure 6b). We therefore hypothesized that the capacity for IL-12 and IL-18 to induce IFN- $\gamma$ might be reduced in $\mathrm{Hjv}^{-/-}$mice. To test this hypothesis, we examined the signaling pathways downstream of IL-12 and IL-18. Previous studies showed that IL-18 regulates IFN- $\gamma$ via the MAP kinase (MAPK) pathway, [47] and IL-12 drives the phosphorylation of Stat4 to induce IFN- $\gamma$ expression. [48] To investigate the role of these two pathways, we measured phosphorylated MAPK proteins and phosphorylated Stat4 in macrophages stimulated with heat-killed $\mathrm{E}$. coli. We found no defect in $\mathrm{Hjv}^{-/-}$ macrophages with respect to p38 (Figure 4c), Erk1/2, or Jnk phosphorylation (Figure 6c). However, E. coli stimulated phosphorylation of Stat4 was significantly impaired in $\mathrm{Hjv}^{-/-}$macrophages compared with wildtype macrophages (Figure 6d). Consistent with reduced Stat4 phosphorylation, Jak2 phosphorylation was also reduced in $\mathrm{Hjv}^{-/-}$macrophages compared with wild-type cells (Figure 6e). Finally, we performed in vitro co-immunoprecipitation experiments using HEK293 cells co-transfected with Flag-tagged HJV and Myc-tagged IL-12RB1 (the beta-1 subunit of the IL-12 receptor). Although weakly pulled down by IL-12RB1-Myc, HJV-Flag was highly effective at pulling down IL-12RB1-Myc (Figure 6f), suggesting that HJV may play a direct role in IL-12 signaling. Taken together, these results suggest that HJV may regulate IFN- $\gamma$ in macrophages via the IL-12/Jak2/ Stat4 pathway.

\section{Discussion}

A clear relationship between hemochromatosis and infection has been established by several groups [49-52]. The majority of these results suggest that both HFE and Hepcidin (encoded by the HFE and HAMP genes, respectively) play a protective role against bacterial infection in human and mouse. Here, we performed a novel screen using several hemochromatosis mouse models to investigate the mechanisms that underlie the putative link between iron metabolism and immunity. Importantly, our in vivo screening strategy differed from previous studies $[5,18]$ in that we focused on the acute infection phase. Thus, our bacterial dose was based on the lethal dose established for modeling severe peritonitis in $129 / \mathrm{svj}$ mice [18].

Of the three hemochromatosis mouse models in our initial screen, we found that only $\mathrm{Hjv}^{-/-}$mice were highly susceptible to bacterial infection, and we excluded iron burden as the main contributing factor using iron-deficient $\mathrm{Hjv}^{-/-}$( $\mathrm{Hjv}^{-1-}$-ID) mice. However, under standard dietary conditions, splenic iron content is lower in $\mathrm{Hjv}^{-/-}$mice than in wild-type mice [7], and placing $\mathrm{Hjv}^{--}$mice on an iron-deficient diet lowered iron content in the macrophages even further (Supplementary Figure S1A). These factors complicate the phenotype of $\mathrm{Hjv}^{-/-}$mice and may have affected survival. Therefore, after we identified which specific immune cells (that is, macrophages and neutrophils) are functionally impaired in $\mathrm{Hjv}^{-/-}$mice, we performed survival experiments using $\mathrm{Hj}^{\text {fllfl }}$; LysM-Cre ${ }^{+}$mice, in which $\mathrm{Hjv}$ expression is deleted selectively in macrophages and neutrophils. Our results revealed that $\mathrm{Hjv}^{\text {fllff}} ; \mathrm{LysM}$-Cre $\mathrm{C}^{+}$mice have a survival profile similar to $\mathrm{Hjv}^{-l-}$-ID mice. Given that the iron content in the major organs and macrophages of $\mathrm{Hjv}^{\text {fllfl}} ; \mathrm{LysM}-\mathrm{Cre}^{+}$ mice was similar to wild-type littermates (Supplementary Figure S1B and C), we conclude that iron burden does not play a major role in the high susceptibility of $\mathrm{Hjv}^{-/-}$mice to bacterial infection.

We observed significantly reduced levels of circulating IFN- $\gamma$ in $\mathrm{Hjv}^{-/-}$mice $6 \mathrm{~h}$ after bacterial infection. IFN- $\gamma$ is primarily secreted by Thelper type 1 (Th1) cells [53] and NK cells [54]. However, given the time frame of the increased IFN- $\gamma$ levels (that is, within $6 \mathrm{~h}$ ), the principal source of IFN- $\gamma$ during the early stages of infection is likely not Th1 or NK cells. Interestingly, peritoneal macrophages and neutrophils have been reported as a source of IFN- $\gamma$ [55-58], although this remains controversial [59]; nevertheless, it is worth noting that Schleicher et al. [59] treated peritoneal cells with IL-12, IL-18, and LPS for $72 \mathrm{~h}$, which differs from our bacterial infection model (6-24 h). A recent study in mice also found that Gr- $1^{+}$ cells produce IFN- $\gamma$ in the early stages of Streptococcus infection, and these cells are responsible for promoting the survival of infected mice [35]. We therefore conclude that peritoneal phagocytes secrete IFN- $\gamma$, thereby self-activating via an autocrine pathway, providing an essential step in fighting peritoneal infection and improving survival.

Our results indicate that $H j v$ deletion affects the IL-12/Jak2/Stat4 signaling pathway, but not the IL-18/MAPK pathway. Nevertheless, additional research is warranted in order to better understand the underlying mechanisms.

In conclusion, we identified a novel role for HJV in mediating bacterial clearance via macrophages. Our findings indicate that HJV may serve as a potential target for boosting protection against bacterial peritoneal infection, thereby improving clinical outcome. 


\section{Materials and Methods}

Mice

$H f e^{-l-}, H j v^{-1-}, F p n 1^{f l o x f l o x}, H j v^{f f o x f f l o x}$ and wild-type mice were maintained on the 129S6/SvEvTac background and were housed in a specific pathogen-free animal facility [9, 14, 60, 61]. FpnI knockout in macrophages $\left(F p n 1^{f l f l} ; L y s M-C r e^{+}\right)$was achieved by crossing LysM-Cre mice [62] with Fpn floxflox mice, and Hjv knockout in macrophages $\left(\mathrm{Hjv}^{\mathrm{fllf}} ; \mathrm{LysM}-\mathrm{Cre}^{+}\right)$was achieved by crossing LysM-Cre mice [62] with Hjv $v^{\text {floxlflox }}$ mice. LysM-Cre mice were maintained as heterozygotes. All animal experiments were approved and performed in accordance with guidelines established by the Institutional Animal Care and Use Committee of the School of Medicine, Zhejiang University.

\section{In vivo infection models and bacterial growth measurements}

Mice were infected with various bacterial species via i.p. or i.v. injection in order to induce peritonitis and bacteremia, respectively. S. typhimurium, E. coli and $S$. aureus were grown in $\mathrm{LB}$ and isolated on LB agar plates. For the IFN- $\gamma$ rescue experiments, 10 units of IFN- $\gamma$ in saline (or saline alone) were subcutaneously injected into the right flank of the mice, immediately followed by an i.p. injection of E. coli TOP10 bacteria, which carries the GFP gene on the Puc19 plasmid [63]. Organ/peritoneal cavity colony-forming units (CFUs) were determined by plating dilutions of organ homogenates or peritoneal lavage fluid on LB plates.

\section{Dietary induction of iron deficiency}

To induce iron deficiency, 4-week-old mice were fed a diet containing reduced iron content $\left(0.9 \mathrm{mg} \mathrm{Fe} \mathrm{kg}^{-1}\right.$, AIN-76A-diet, D08080402, Research Diets, Inc., New Brunswick, NJ, USA) for 4 weeks. Standard diet contained $50 \mathrm{mg} \mathrm{Fe} \mathrm{kg}^{-1}$, (AIN-76A-diet, D08080401, Research Diets, Inc.).

\section{Phagocytosis assay and macrophage killing assays}

For the phagocytosis assay, thioglycollate-stimulated peritoneal macrophages were incubated with Alexa Fluor 488-conjugated heat-killed E. coli (Molecular Probes) for $1 \mathrm{~h}$. Extracellular fluorescence was then quenched by adding $100 \mu \mathrm{l}$ of trypan blue [64]. Cells were then washed in cold PBS and examined using fluorescence microscopy or flow cytometry (FACS analysis). For the killing assay, thioglycollate-stimulated peritoneal macrophages were incubated with TOP10 E. coli for $20 \mathrm{~min}$. The macrophages were then washed with phosphatebuffered saline (PBS) to remove the bacteria, incubated in $100 \mu \mathrm{g} \mathrm{ml}^{-1}$ gentamycin in DMEM for $20 \mathrm{~min}$ (to kill extracellular bacteria), and then incubated for an additional $120 \mathrm{~min}$ in $25 \mu \mathrm{g} \mathrm{ml}^{-1}$ gentamycin in DMEM. CFUs were then measured from macrophage lysates $[40,65]$. In some experiments, the cells were pretreated for $12 \mathrm{~h}$ with IFN- $\gamma$ (Peprotech) in the presence or absence of IFN- $\gamma$-neutralizing antibody (NeuAb; bp0055, Bio X Cell) prior to adding the bacteria.

\section{ELISA}

ELISA kits for measuring IL-6, TNF- $\alpha$ and IFN- $\gamma$ were purchased from R\&D Systems. ELISA kits for measuring IL-12 and IL-18 were purchased from Pierce. Sera were collected from E. coli-infected wild-type and $\mathrm{Hjv}^{-1-}$ mice at indicated time. Briefly, $50 \mu \mathrm{l}$ serum, blank or standard were added in 96-well plate, incubated at room temperature for $2 \mathrm{~h}$, washed by wash buffer for five times. Then, $100 \mu \mathrm{l}$ conjugated antibodies were incubated at room temperature for $2 \mathrm{~h}$, washed by wash buffer for five times. TMB mix $(100 \mu \mathrm{l})$ was added into wells for $30 \mathrm{~min}$, and stop solution was then added to stop the reaction. OD values were read at $450 \mathrm{~nm}$ by Microplate reader (Molecular Devices, Sunnyvale, CA, USA).

\section{Antibodies}

Primary antibodies: rabbit anti-pStat1 (1:1000, Cell Signaling Technology [CST, Boston, MA, USA]), rabbit anti-Stat1 (1:1000, CST), rabbit anti-pErk1/2 (1:1000, CST), rabbit antiErk1/2 (1:1000, CST), mouse anti-pJnk (1:1000, CST), rabbit anti-Jnk (1:1000, CST), rabbit anti-pStat4 (1:500, Santa Cruz (Santa Cruz, CA, USA)), rabbit anti-Stat4 (1:1000, CST), rabbit anti-pJak2 (1:500, CST), rabbit anti-Jak2 (1:1000, CST), rabbit anti-pSmad1/5/8 (1:1000, CST), rabbit anti-Smad1 (1:1000, CST), rabbit anti-pSmad3 (1:1000, CST), rabbit anti-Smad3 (1:1000, CST), rabbit anti-FLAG (1:1000, CST), mouse antiMyc (1:1000, CST), or mouse anti- $\beta$-actin (Sigma, San francisco, CA, USA). Secondary antibodies: peroxidase-conjugated goat anti-Rabbit or Goat anti mouse IgG (Proteintech (Chicago, IL, USA), 1:2000).

\section{Western blot analysis}

Western blot was perform as previously described [9]. Briefly, cells/tissues were lysed by RIPA buffer (Beyotime, Shanghai, China) with protease inhibitor cocktail (Sigma) for $10 \mathrm{~min}$; Sonicate for $10 \mathrm{~s}$ to complete cell lysis and shear DNA followed by adding loading buffer (containing 5\% $\beta$-Me). Then samples were heated to $95-100^{\circ} \mathrm{C}$ for $5 \mathrm{~min}$ (alternatively $37^{\circ} \mathrm{C} 30 \mathrm{~min}$ for membrane protein detection), cool on ice and microcentrifuge for $5 \mathrm{~min}$. Samples were loaded onto SDS-PAGE gel and then electrotransfer to PVDF membrane (Bio-Rad, Hercules, CA, USA). The transferred membrane was incubated in blocking buffer ( $5 \%$ skim milk in TBST) for $1 \mathrm{~h}$ followed by incubation with primary antibody overnight at $4{ }^{\circ} \mathrm{C}$. Membrane was washed three times for $10 \mathrm{~min}$ each with TBST, and incubated with HRP-linked secondary antibody for $1 \mathrm{~h}$ at room temperature. Wash three times for $10 \mathrm{~min}$ each with TBST. After incubation with ECL (Pierce (Rockford, IL, USA), Thermo (Waltham, MA, USA)) mixture for $5 \mathrm{~min}$, wrap the membrane in plastic and expose to X-ray film. Co-IP experiments were performed using anti-Flag (1:50, CST) and anti-Myc $(1: 1000$, CST) antibodies.

\section{Real-time quantitative PCR}

Total RNA was isolated from peritoneal macrophages or liver tissue using Trizol (Invitrogen, Carlsbad, CA, USA). Realtime PCR was then performed using two-step quantitative realtime PCR with the primer pairs listed in Supplementary Table $\mathrm{S} 1$. The expression level of each target gene was normalized to the corresponding $\beta$-actin mRNA level. 
Expression of Hjv in RAW264.7 macrophages

$\mathrm{Hjv}$-expressing constructs were cloned into the pCMV-3Tag$3 \mathrm{~A}$ vector and transfected into RAW264.7 cells using the FuGENE HD transfection reagent (Promega, Madison, WI, USA).

\section{Quantification of nitric oxide (NO) and ROS}

NO concentration was measured using the Griess assay [66]. $50 \mu \mathrm{l}$ cell medium, blank or standard control were added into a 96-well plate, followed by adding $50 \mu \mathrm{l}$ Griess reagent I and II, incubated at room temperature for $10 \mathrm{~min}$, OD values were read at $540 \mathrm{~nm}$ by Microplate reader (Molecular Devices). Intracellular reactive oxygen species were measured using the dichloro-dihydro-fluorescein diacetate (DCFH-DA) method [67]. HK-E. coli-stimulated macrophages in 6-well plate were incubated in serum-free DMEM-containing $10 \mu \mathrm{M}$ DCFH-DA for $20 \mathrm{~min}$ at $37^{\circ} \mathrm{C}$ in cell culture hood. Cells were then detached by trypsin digestion and followed by FACS analysis at the excitation wavelength of $488 \mathrm{~nm}$ and emission wavelength of $525 \mathrm{~nm}$

\section{Statistical analysis}

All summary data are presented as the mean \pm s.e.m. The log-rank test or Mann-Whitney $U$-test was used to analyze the Kaplan-Meier survival curves. The Student's $t$-test was used to compare two groups, and an ANOVA was used to compare multiple groups. Differences with a $P$-value $<0.05$ were considered significant.

\section{Conflict of Interest}

The authors declare no conflict of interest.

\section{Acknowledgements}

We are grateful to Dr Nancy Andrews for generously providing the $\mathrm{Hfe}^{-/-}, \mathrm{Hjv}^{-/-}, \mathrm{Hj}^{\text {flox/flox }}$, and FpnI $\mathrm{I}^{\text {flox } f f o x}$ mice. We also thank Dr Baoxue Ge at Tongji University for providing the E. coli TOP10 strain carrying the GFP gene on the Puc-19 plasmid. This work was supported by grants from the National Natural Science Foundation of China (31530034, 31330036, and 31225013 to FW; 31570791 and 91542205 to JM), and Zhejiang Provincial Natural Science Foundation of China (LZ15H160002 to JM). We thank members of the Wang and Min laboratories for discussion.

\section{Author contributions}

QW, YS, FW and JM designed the experiments. QW, YS, YT, PA, HW, ZZ, JW and HG performed the experiments. QW, YS, YT, FW and JM analyzed the data. QW, YS, TZ, FW and $\mathrm{JM}$ drafted and revised the manuscript.

\section{References}

1 Bullen JJ, Rogers HJ. Bacterial iron metabolism and immunity to Pasteurella septica and Escherichia coli. Nature 1969; 224: 380-382.

2 Farnaud S, Evans RW. Lactoferrin--a multifunctional protein with antimicrobial properties. Mol Immunol 2003; 40: 395-405.

3 Park $\mathrm{CH}$, Valore EV, Waring AJ, Ganz T. Hepcidin, a urinary antimicrobial peptide synthesized in the liver. J Biol Chem 2001; 276: 7806-7810.

4 De Domenico I, Zhang TY, Koening CL et al. Hepcidin mediates transcriptional changes that modulate acute cytokine-induced inflammatory responses in mice. $J$ Clin Invest 2010; 120: 2395-2405.

5 Flo TH, Smith KD, Sato S et al. Lipocalin 2 mediates an innate immune response to bacterial infection by sequestrating iron. Nature 2004; 432: 917-921.

6 Nairz M, Theurl I, Schroll A et al. Absence of functional Hfe protects mice from invasive Salmonella enterica serovar Typhimurium infection via induction of lipocalin-2. Blood 2009; 114: 3642-3651.

7 Niederkofler V, Salie R, Arber S. Hemojuvelin is essential for dietary iron sensing, and its mutation leads to severe iron overload. J Clin Invest 2005; 115: 2180-2186.

8 Armitage AE, Eddowes LA, Gileadi U et al. Hepcidin regulation by innate immune and infectious stimuli. Blood 2011; 118: 4129-4139.

9 Zhang Z, Zhang F, An P et al. Ferroportin1 deficiency in mouse macrophages impairs iron homeostasis and inflammatory responses. Blood 2011; 118: 1912-1922.

10 Naz N, Malik IA, Sheikh N et al. Ferroportin-1 is a 'nuclear'-negative acute-phase protein in rat liver: a comparison with other iron-transport proteins. Lab Invest 2012; 92: $842-856$.

11 Frank KM, Schneewind O, Shieh WJ. Investigation of a researcher's death due to septicemic plague. $N$ Engl J Med 2011; 364: 2563-2564.

12 Andriopoulos B Jr, Corradini E, Xia Y et al. BMP6 is a key endogenous regulator of hepcidin expression and iron metabolism. Nat Genet 2009; 41: 482-487.

13 Papanikolaou G, Samuels ME, Ludwig EH et al. Mutations in HFE2 cause iron overload in chromosome 1q-linked juvenile hemochromatosis. Nat Genet 2004; 36: 77-82.

14 Huang FW, Pinkus JL, Pinkus GS, Fleming MD, Andrews NC. A mouse model of juvenile hemochromatosis. J Clin Invest 2005; 115: 2187-2191.

15 Corradini E, Babitt JL, Lin HY. The RGM/DRAGON family of BMP co-receptors. Cytokine Growth Factor Rev 2009; 20: 389-398.

16 Muramatsu R, Kubo T, Mori M et al. RGMa modulates $\mathrm{T}$ cell responses and is involved in autoimmune encephalomyelitis. Nat Med 2011; 17: 488-494.

17 Xia Y, Cortez-Retamozo V, Niederkofler V et al. Dragon (repulsive guidance molecule b) inhibits IL-6 expression in macrophages. J Immunol 2011; 186: 1369-1376.

18 Houghton AM, Hartzell WO, Robbins CS, Gomis-Ruth FX, Shapiro SD. Macrophage elastase kills bacteria within murine macrophages. Nature 2009; 460: 637-641. 
19 Paradkar PN, De Domenico I, Durchfort N, Zohn I, Kaplan J, Ward DM. Iron depletion limits intracellular bacterial growth in macrophages. Blood 2008; 112: 866-874.

20 Sunder-Plassmann G, Patruta SI, Horl WH. Pathobiology of the role of iron in infection. Am J Kidney Dis 1999; 34: S25-S29.

21 Chang M, Jin W, Sun SC. Peli1 facilitates TRIF-dependent Toll-like receptor signaling and proinflammatory cytokine production. Nat Immunol 2009; 10: 1089-1095.

22 Starnes HF Jr, Pearce MK, Tewari A, Yim JH, Zou JC, Abrams JS. Anti-IL-6 monoclonal antibodies protect against lethal Escherichia coli infection and lethal tumor necrosis factor-alpha challenge in mice. J Immunol 1990; 145: 4185-4191.

23 Haziot A, Ferrero E, Kontgen F et al. Resistance to endotoxin shock and reduced dissemination of gramnegative bacteria in CD14-deficient mice. Immunity 1996; 4: 407-414.

24 Dale DC, Boxer L, Liles WC. The phagocytes: neutrophils and monocytes. Blood 2008; 112: 935-945.

25 Henderson RB, Hobbs JA, Mathies M, Hogg N. Rapid recruitment of inflammatory monocytes is independent of neutrophil migration. Blood 2003; 102: 328-335.

26 Keisari Y, Braun L, Flescher E. The oxidative burst and related phenomena in mouse macrophages elicited by different sterile inflammatory stimuli. Immunobiology 1983; 165: 78-89.

27 Schroder K, Hertzog PJ, Ravasi T, Hume DA. Interferongamma: an overview of signals, mechanisms and functions. J Leukoc Biol 2004; 75: 163-189.

28 Gessani S, Belardelli F. IFN-gamma expression in macrophages and its possible biological significance. Cytokine Growth Factor Rev 1998; 9: 117-123.

29 Yeaman GR, Collins JE, Currie JK, Guyre PM, Wira CR, Fanger MW. IFN-gamma is produced by polymorphonuclear neutrophils in human uterine endometrium and by cultured peripheral blood polymorphonuclear neutrophils. J Immunol 1998; 160: 5145-5153.

30 Cairo G, Recalcati S, Mantovani A, Locati M. Iron trafficking and metabolism in macrophages: contribution to the polarized phenotype. Trends Immunol 2011; 32: 241-247.

31 Gennari R, Alexander JW, Eaves-Pyles T. IFN-gamma decreases translocation and improves survival following transfusion and thermal injury. J Surg Res 1994; 56: 530-536.

32 Miles RH, Paxton TP, Dries DJ, Gamelli RL. Interferongamma increases mortality following cecal ligation and puncture. J Trauma 1994; 36: 607-611.

33 Dalton DK, Pitts-Meek S, Keshav S, Figari IS, Bradley A, Stewart TA. Multiple defects of immune cell function in mice with disrupted interferon-gamma genes. Science 1993; 259: 1739-1742.

34 Simmons CP, Goncalves NS, Ghaem-Maghami M et al. Impaired resistance and enhanced pathology during infection with a noninvasive, attaching-effacing enteric bacterial pathogen, Citrobacter rodentium, in mice lacking IL-12 or IFN-gamma. J Immunol 2002; 168: 1804-1812.
35 Matsumura T, Ato M, Ikebe T, Ohnishi M, Watanabe H, Kobayashi $\mathrm{K}$. Interferon-gamma-producing immature myeloid cells confer protection against severe invasive group A Streptococcus infections. Nat Commun 2012; 3: 678.

36 Karupiah G, Xie QW, Buller RM, Nathan C, Duarte C, MacMicking JD. Inhibition of viral replication by interferon-gamma-induced nitric oxide synthase. Science 1993; 261: 1445-1448.

37 Xie QW, Whisnant R, Nathan C. Promoter of the mouse gene encoding calcium-independent nitric oxide synthase confers inducibility by interferon gamma and bacterial lipopolysaccharide. J Exp Med 1993; 177: 1779-1784.

38 Jun CD, Choi BM, Hoon R et al. Synergistic cooperation between phorbol ester and IFN-gamma for induction of nitric oxide synthesis in murine peritoneal macrophages. J Immunol 1994; 153: 3684-3690.

39 Zhang X, Alley EW, Russell SW, Morrison DC. Necessity and sufficiency of beta interferon for nitric oxide production in mouse peritoneal macrophages. Infect Immun 1994; 62: 33-40.

40 Vazquez-Torres A, Jones-Carson J, Mastroeni P, Ischiropoulos H, Fang FC. Antimicrobial actions of the NADPH phagocyte oxidase and inducible nitric oxide synthase in experimental salmonellosis. I. Effects on microbial killing by activated peritoneal macrophages in vitro. $J$ Exp Med 2000; 192: 227-236.

41 Babitt JL, Huang FW, Wrighting DM et al. Bone morphogenetic protein signaling by hemojuvelin regulates hepcidin expression. Nat Genet 2006; 38: 531-539.

42 Kwon SJ, Lee GT, Lee JH, Kim WJ, Kim IY. Bone morphogenetic protein- 6 induces the expression of inducible nitric oxide synthase in macrophages. Immunology 2009; 128: e758-e765.

43 Wu X, Yung LM, Cheng WH et al. Hepcidin regulation by BMP signaling in macrophages is lipopolysaccharide dependent. PLoS ONE 2012; 7: e44622.

44 Yu PB, Deng DY, Lai CS et al. BMP type I receptor inhibition reduces heterotopic [corrected] ossification. Nat Med 2008; 14: 1363-1369.

45 Dinarello CA. Interleukin-18, a proinflammatory cytokine. Eur Cytokine Netw 2000; 11: 483-486.

46 Magram J, Connaughton SE, Warrier RR et al. IL-12-deficient mice are defective in IFN gamma production and type 1 cytokine responses. Immunity 1996; 4: 471-481.

47 Kalina U, Kauschat D, Koyama N et al. IL-18 activates STAT3 in the natural killer cell line 92, augments cytotoxic activity, and mediates IFN-gamma production by the stress kinase p38 and by the extracellular regulated kinases p44erk-1 and p42erk-21. J Immunol 2000; 165: 1307-1313.

48 Nakahira M, Ahn HJ, Park WR et al. Synergy of IL-12 and IL-18 for IFN-gamma gene expression: IL-12-induced STAT4 contributes to IFN-gamma promoter activation by up-regulating the binding activity of IL-18-induced activator protein 1. J Immunol 2002; 168: 1146-1153.

49 Schaible UE, Collins HL, Priem F, Kaufmann SH. Correction of the iron overload defect in beta-2microglobulin knockout mice by lactoferrin abolishes 
their increased susceptibility to tuberculosis. $J$ Exp Med 2002; 196: 1507-1513.

50 Wang L, Johnson EE, Shi HN, Walker WA, Wessling-Resnick M, Cherayil BJ. Attenuated inflammatory responses in hemochromatosis reveal a role for iron in the regulation of macrophage cytokine translation. J Immunol 2008; 181: 2723-2731.

51 Gomes-Pereira S, Rodrigues PN, Appelberg R, Gomes MS. Increased susceptibility to Mycobacterium avium in hemochromatosis protein HFE-deficient mice. Infect Immun 2008; 76: 4713-4719.

52 Arezes J, Jung G, Gabayan V et al. Hepcidin-induced hypoferremia is a critical host defense mechanism against the siderophilic bacterium Vibrio vulnificus. Cell Host Microbe 2015; 17: 47-57.

53 Kasahara T, Hooks JJ, Dougherty SF, Oppenheim JJ. Interleukin 2-mediated immune interferon (IFN-gamma) production by human T cells and T cell subsets. J Immunol 1983; 130: 1784-1789.

54 Scharton TM, Scott P. Natural killer cells are a source of interferon gamma that drives differentiation of $\mathrm{CD}^{+} \mathrm{T}$ cell subsets and induces early resistance to Leishmania major in mice. J Exp Med 1993; 178: 567-577.

55 Salins S, Newton C, Widen R, Klein TW, Friedman H. Differential induction of gamma interferon in Legionella pneumophila-infected macrophages from BALB/c and A/J mice. Infect Immun 2001; 69: 3605-3610.

56 Puddu P, Fantuzzi L, Borghi $\mathrm{P}$ et al. IL-12 induces IFN-gamma expression and secretion in mouse peritoneal macrophages. J Immunol 1997; 159: 3490-3497.

57 Kirby AC, Yrlid U, Wick MJ. The innate immune response differs in primary and secondary Salmonella infection. J Immunol 2002; 169: 4450-4459.

58 Yin J, Ferguson TA. Identification of an IFN-gammaproducing neutrophil early in the response to Listeria monocytogenes. J Immunol 2009; 182: 7069-7073.

59 Schleicher U, Hesse A, Bogdan C. Minute numbers of contaminant $\mathrm{CD}^{+} \mathrm{T}$ cells or $\mathrm{CD} 11 \mathrm{~b}^{+} \mathrm{CD} 11 \mathrm{c}^{+} \mathrm{NK}$ cells are the source of IFN-gamma in IL-12/IL-18-stimulated mouse macrophage populations. Blood 2005; 105: 1319-1328.

60 Wu Q, Wang H, An P et al. HJV and HFE Play Distinct Roles in Regulating Hepcidin. Antioxid Redox Signal 2015; 22: $1325-1336$.
61 Chen W, Huang FW, de Renshaw TB, Andrews NC. Skeletal muscle hemojuvelin is dispensable for systemic iron homeostasis. Blood 2011; 117: 6319-6325.

62 Clausen BE, Burkhardt C, Reith W, Renkawitz R, Forster I. Conditional gene targeting in macrophages and granulocytes using LysMcre mice. Transgenic Res 1999; 8: 265-277.

63 Kong L, Sun L, Zhang H et al. An essential role for RIG-I in toll-like receptor-stimulated phagocytosis. Cell Host Microbe 2009; 6: 150-161.

64 Soehnlein O, Kai-Larsen Y, Frithiof R et al. Neutrophil primary granule proteins HBP and HNP1-3 boost bacterial phagocytosis by human and murine macrophages. $J$ Clin Invest 2008; 118: 3491-3502.

65 Gilberthorpe NJ, Lee ME, Stevanin TM, Read RC, Poole RK. NsrR: a key regulator circumventing Salmonella enterica serovar Typhimurium oxidative and nitrosative stress in vitro and in IFN-gamma-stimulated J774.2 macrophages. Microbiology 2007; 153: 1756-1771.

66 Leopold Wager CM, Hole CR, Wozniak KL, Olszewski MA, Wormley FL Jr. STAT1 signaling is essential for protection against Cryptococcus neoformans infection in mice. J Immunol 2014; 193: 4060-4071.

67 Soumyarani VS, Jayakumari N. Oxidatively modified high density lipoprotein promotes inflammatory response in human monocytes-macrophages by enhanced production of ROS, TNF-alpha, MMP-9, and MMP-2. Mol Cell Biochem 2012; 366: 277-285.

(Supplementary information is linked to the online version of the paper on the Cell Discovery website.)

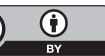

This work is licensed under a Creative Commons Attribution 4.0 International License. The images or other third party material in this article are included in the article's Creative Commons license, unless indicated otherwise in the credit line; if the material is not included under the Creative Commons license, users will need to obtain permission from the license holder to reproduce the material. To view a copy of this license, visit http://creativecommons.org/licenses/by/4.0/

(C) The Author(s) 2017 